Article

\title{
Thinking with Irigaray: On Asian Women as Objects of Conquest and Exchange
}

Elaine M. Lazaro

\begin{abstract}
Luce Irigaray's feminism goes beyond the mere assertion of female equality in a male-centered world. She argues that the cultivation of a feminine culture as opposed to a culture partial to the masculine will merely form a dyad. She saw beyond the futile fights for equality in a male-centered world, and hence campaigned for a more intensive revolution and for the recognition of sexual difference. In this essay, I reflect on Luce Irigaray's feminism while narrating the plight of Asian, particularly but not limited to Chinese, Syrian, and Yemeni women. I mainly aim to explore how Irigaray's kind of feminism, which carry clear traces of the philosophy of difference and anti-commodification, articulate the subjugations suffered by the said group of women. Using Irigaray's language, I show here the forms of how the women are rendered territories of conquests, spoils of war, and merchandises or objects of exchange.
\end{abstract}

Keywords: Irigaray, violence, feminism, philosophy of difference

\section{The Totalization of the Maternal Body}

The logic of the same is then a system that negates differences. Luce Irigaray regards it as the most dangerous philosophical, cultural and symbolic construction man has ever contrived because it reduces the subject to one.

-Florinda Trani, "From the Same to the Other"

$\mathrm{W}$ hile banned in 1911, what used to be the "art" of foot binding continued to flourish until the late 1930s in some rural areas in China. ${ }^{1}$ Then considered a marker of beauty and status, it was,

${ }^{1}$ Lucy Crossley, "PICTURED: The last living Chinese women with bound feet more than 100 years after the centuries-old symbol of beauty and status was banned," in Mail Online (8 June 2014), <http://www.dailymail.co.uk/news/article-2652228/PICTURED-The-livingChinese-women-bound-feet-100-years-centuries-old-symbol-beauty-status-banned.html.> .

(c) 2017 Elaine M. Lazaro

http://www.kritike.org/journal/issue 20/lazaro june2017.pdf

ISSN 1908-7330 
however, accomplished with techniques that are rather tortuous. In as early as the age of four, the girl's feet were prepared for foot binding by drenching them in a mixture of animal blood and herbs. Once softened, each foot's toes would be curled backward, pressed against the sole until the bones break. Walking with lotus feet was seen very erotic at the time; it forces the female to have an unbalanced and fragile gait and to walk in child-like steps. Resembling hoofs, the shoes used in foot binding alter one's bone structure, giving the women a more arched behind. The lotus feet were not cheap because they needed maintenance. They had to be washed regularly and the bandages had to be changed from time to time-in private, because while visually appealing, a bound set of feet smells horrendous.

Meanwhile, in France in the 1970s, Luce Irigaray gave voice, indirectly, to the horrors of the putrid smell of the lotus feet, and its variations across cultures, in a book that was also her dissertation, which cost her the hard-earned place she worked hard for in the academe, The Speculum of the Other Woman. Thus, what was supposed to break through the domination of the masculine culture only proved the strength of such dominion.

Using a language that somehow resembles the polyphony of poeticprose and philosophy, Irigaray tells us the need for a Copernican revolution in the male imaginary. ${ }^{2}$ This revolution is not merely a reversal of what should revolve around which heavenly body i.e., gender. It is moreover a critique of what Irigaray describes as man's self-proclaimed ascent into being the sun around which the earth is expected to revolve. Thus, the revolution subsequently signifies man's self-imposed distance from the very womb or earth where it came from. This forgetfulness of such material and necessary relation gives man the illusion that he is in an elect place to treat the female as an object for his inspection. Irigaray further likens this objectification into a game of Chinese boxes that is infinitely receding. ${ }^{3}$ Man looks for the definition of the female after his own image, which is a popular narrative across cultures, such as the Biblical depiction of Eve's birth from Adam's ribs.

Nonetheless, the definition of a female sought through man is something that cannot be found, because the essence of being a female is not something to be inspected or opened as if it is being concealed. There really are no representations for her, "no doubt...she is said to be restless and unstable...it is quite rigorously true that she is never exactly the same." 4 In other words, every attempt to find out the essence of the female is a failure because it is something that cannot be grasped. Irigaray's take on the female as a feminine other echoes Levinas' exposition of the Other as complete

\footnotetext{
${ }^{2}$ Luce Irigaray, Speculum of the Other Woman, trans. by Gillian C. Gill, (Ithaca New York: Cornell University Press, 1985), 133-134.

${ }^{3}$ Ibid., 134.

${ }^{4}$ Ibid.

(c) 2017 Elaine M. Lazaro

http://www.kritike.org/journal/issue 20/lazaro june2017.pdf

ISSN 1908-7330
}

(c) BY-NC-ND 
alterity, wherein any form of absorption into the same, which even includes subtle forms of terrorism such as negative punning, is considered violence.

Furthermore, the desire to see not only the female's body for enjoyment, but also to see her essence by gazing at her shows the violence of the primacy of vision in Western thought. In line with this, it must be noted that Irigaray's speculum refers to a mirror ${ }^{5}$ i.e., a mirror or glass reflector upon which a woman sees herself as a mirage that she then presents to the world. Moreover, the term "speculum" also refers to a plastic of metal instrument used in dilating the female genital for inspection. Echoing Levinas in Irigaray's thought, vision, hence, is in a way enjoyment already. And because the woman is not allowed to speak for her own-unless in a language partial to the male imaginary according to Irigaray-she remains an object or a work of art for one's pleasure. She is voiceless, and because she is mute, she appears to remain a face, if I may describe it in a Levinasian way, which is a thing among things that conceals her difference instead of exposing it.

This enjoyment of vision or gaze is linked into concepts as if these concepts are hands that grasp. Thus, in Irigaray, there is an intimate link between gazing and grasping. ${ }^{6}$ Concepts or terms are "prosthesis" of gazing used to dominate the feminine other. She says that "In a way our language imposes... verbal construction that does not coincide with the form that it does not have as living." 7 Irigaray puts into question the predominant language that is partial to the male imaginary. It is a language violent to the female because it cages or grasps her in terms or concepts that attempt to totalize her radical alterity. It grips her and forgets that she is a living and dynamic being that always overflows these concepts because of her difference. Further, these concepts function as hands that hold, which reminds us of that capitalistic attitude to possess, to own, and to hoard. Being gripped in concepts, the woman is boxed and is understood within the terms of the sameness of the order. The woman is hence commoditized, priced, and sold, which is to say she is rendered a material that can be possessed.

About a month before I began to write this essay (circa 2015), there was news about European immigrants, specifically girls who are teenagers or are in their early 20s, who were lured to go to Syria from Europe on their own. Capitalizing on these young girls' yearning for identity and a sense of complete belonging, the Islamist extremists enticed the young women who

\footnotetext{
${ }^{5}$ Elizabeth Hirsh and Olson, Gary. "Je-Luce Irigaray," trans. by Elizabeth Hirsh and Gaetan Brulotte, in JAC: A Journal of Rhetoric, Culture, and Politics, 16:3 (1995): 346.

${ }^{6}$ Irigaray, Speculum of the Other Woman, 138.

7 Luce Irigaray, "Being Two, How Many Eyes Have We?" in Paragraph: A Journal of Modern Critical Theory, 25:3 (2002): 144.
} 
are mostly from Muslim communities, but one was noted to be a Jew, to leave their relatively comfortable lives with the pretext that they will be doing something big, i.e., they will serve for their sisters and brothers in Syria.

When Foad from France discovered that his missing sister Nora kept two Facebook accounts and seemingly lived a double life, he understood that she had gone to Syria. He quit his job in search of Nora, and when he was able to track her down finally, she was not, however, set free. It was apparently easier for young boys to quit. But for girls who are expected to be spoils of war, it would be more difficult. They are considered machines to regenerate the loss of manpower supply. This reaffirms Irigaray's metaphor of the female as the 'earth,' which does not only refer to her body as it is conquered by the penis, but also to her very materiality 8 and to her capacity to reproduce. In this case, she is valued only for her womb, or rather as a womb that would carry a supply of individuals who will be used for further conquests and totalizations in the form of wars and dominations. Incidentally, it is not an accident that there were comfort women in Asia during the world war. These Filipino, Korean, and Indonesian women, among others, were turned into comfort women not only for the soldiers' biological necessity for sex. This is also because the conquest of these women was symbol of the subjugation of the homeland.

The maternal body is seen as possession, and as Irigaray says, "man's eye-understood as substitute for the penis-will be able to prospect a woman's sexual parts, seek there new sources of profit." ${ }^{9}$ Establishing the link between the eye or gazing and possession, it can then be said that the maternal body is prostituted by what I propose to call "the political economy of the same." It is of no wonder then that the female body is most harassed and debased for example in pornography as if it is not the same body that has spawned a human being. The maternal body, as if it is foreign to men and as if it is not their "origin," is treated as a property to be utilized, to be named, to be titled, and to be possessed. The political economy of the same, which functions under the logic of identity, ${ }^{10}$ is what is at the face of the Western tradition. It is concerned with similarity, possession, ownership, and gathering. The male sex stands for a tradition that is partial to men, more specifically the violent fiction of the masculine. It is the denial of a tradition that could be represented by the female sex, that is, a sex which is not one, and not even two.

${ }^{8}$ Irigaray, Speculum of the Other Woman, 133-134.

${ }^{9}$ Ibid., 145.

${ }^{10}$ Florinda Trani, "From the Same to the Other," in Paragraph: A Journal of Modern Critical Theory, 25:3 (2002): 57.

(C) 2017 Elaine M. Lazaro

http://www.kritike.org/journal/issue 20/lazaro june2017.pdf

ISSN 1908-7330

(c) BY-NC-ND 
I would like, at this point, to go back to China. While Irigaray was an active participant of feminist movements in Italy - an evidence of how her theory is put into practice-she did not, however, really venture into the experiences of the Chinese or Asian women in general in her feminist philosophy. As such, I reflect here on Chinese, Syrian, Yemen women's experiences, among others, using Irigaray's language. This is because the reflections demonstrate the truth in her thought despite that she is European, and that her diving board is primarily the oppressions, such as the invisibility of the European women. At the same time, these reflections suggest that her theory provide tools in understanding women's places in Asia then and now, and in articulating, if not representing their plight.

In China before, it was evident that a woman's ownership of lotus feet is a mark that she is treated as a property, which also means that she is only and again valued for her body. One function of the lotus feet that is not aesthetic, as we know from history, is to assure that the wife will not venture into the fields of infidelity for she could not physically do so. It implies that the male is assured that the beneficiaries, i.e., their children of his economic labor, are really his own and not someone else's because even while a woman with bound feet can still function almost normally, being still capable to do work in the field or to dance, her movements are always limited by her abnormally small feet (ideally only three inches long). She could not take part in civic or social functions, much more to move elsewhere without the accessory of a help. ${ }^{11}$

Nevertheless, having lotus feet is said to elevate a woman's stand in a society completely partial to men. "Having a daughter with bound feet conferred many potential benefits both on the girl and her family, transforming the biological disadvantage of being born female into a distinct social advantage by increasing her opportunities for making a lucrative marriage." 12

Marie Vento, who commented that historians on the art of foot binding could not seem to locate its true origins, said that what is certain is that it began in the elite classes, which gradually spiraled downward geographically and socially: Poor families, for instance, would then foot-bind their eldest female child so that she could be married off to a man from a welloff clan, while her other younger female siblings were tasked to take care of her and to work in the fields.

While having lotus feet seems to raise a woman's societal worth in a time and place when and where being a male is equivalent to resembling a

\footnotetext{
${ }^{11}$ Marie Vento, "One Thousand Years of Chinese Footbinding: Its Origins, Popularity and Demise," in Fordham University: Internet History Sourcebooks Project (7 March 1998), ed. by Paul Halsall, <http://sourcebooks.fordham.edu/halsall/women/vento.asp $>$.

${ }^{12} \mathrm{Ibid}$.
}

(c) 2017 Elaine M. Lazaro

http://www.kritike.org/journal/issue 20/lazaro june2017.pdf

ISSN 1908-7330 
demigod, the foot-bound women only become a symptom of such phallogocentric society. As Irigaray puts it, she only becomes a tool that supports the "projections and projects" of the phallus, which is the illusory and imaginary symbol of the penis that is perfectly tall and erect. For Irigaray, "She prostitutes the unconscious itself to the ever present projects and projections of masculine consciousness." 13 That being the case, the lotus feet do not really finally carve a space for women in a male-centered China.

Instead, it only elevates the male since the female only succumbs to his right to pick a wife. This is not at all different from having the power to modify one's appearance through cosmetic surgery just to meet the requirements of the marriage agencies in contemporary China. These agencies cater to men with money seeking for women who have this and that qualification (e.g., an oval face, between $5^{\prime} 4^{\prime \prime}$ to $5^{\prime} 6^{\prime \prime}$ in height). The lotus feet, therefore, warn us that what seems to elevate a woman and to make her an equal may actually mar her more if this elevation and equality is still within the terms and conditions of the same. It shows the danger of the attempt to fight for equality in a world whose symbolic order is partial to the masculine because the real problem is beneath, which is the symbolic order that can be seen in language and narratives.

Irigaray saw beyond the futile fights for female equality, and thus what she did first, instead of merely asserting for a female space within a male-centered world, is a cultural anthropology of the same. By examining language, by playing with symbols, and by employing metaphors such as the metaphor of fissures, she traces the origin of a male-centered world. Language and symbols, among others, are what is at the heart of a culture. This being the case, these shape the social order and fuel the logic of identity and sameness. Incidentally, Irigaray also says something related to the lotus feet, which is about the small steps taken by a woman in a world dominated by man, a world that promotes a "lotus feet culture":

Indifferent one, keep still. If you move, you disturb their order. You cause everything to fall apart. You break the circle of their habits, the circularity of their exchanges, their knowledge, their desire: their world. Indifferent one, you must not move or be moved unless they call you. If they say 'come,' then you may go forward, ever so slightly. Measure your steps according to their needor lack of need-for their own image. One or two steps, no more, without exuberance or turbulence. Otherwise,

${ }^{13}$ Irigaray, Speculum of the Other Woman, 141.

(c) 2017 Elaine M. Lazaro

http://www.kritike.org/journal/issue 20/lazaro june2017.pdf

ISSN 1908-7330

(c) BY-NC-ND 
you will smash everything, their mirror, their earth, their mother. You are only a small, insignificant receptacle. ${ }^{14}$

\title{
Women as Merchandise
}

\author{
Hence women's role as fetish-objects, inasmuch as, in \\ exchanges, they are the manifestation and the circulation of a power \\ of the Phallus, establishing relationships of men with each other? \\ -Luce Irigaray, "Women on the Market"
}

Irigaray's metaphor of the maternal body was born only during the second phase of her career. Initially, she played with the metaphor of the lesbian and lesbian relationships as she did an abuse of metaphor of the lips. ${ }^{15}$ Such metaphor makes sense when imagining homosexual sexual intercourse: two lips speaking with each other is an image that calls for a new space for feminine discourse, a new language that is free from masculine domination, and a sexuality that is not dictated by the prevailing order. This relationship emancipates the female from being merely seen as a reproductive tool. It capacitates her as a willing, thinking, and acting subject that can speak for her own and who embraces her own sexuality.

Nonetheless, Irigaray ultimately had to abandon the said metaphor, and instead, then reflected on the image of the mother and of the mother and daughter relationship that had very few representations in history ${ }^{16}$ in the second phase of her career. She realized that the image of the lesbian, two lips speaking as one, would only isolate the female and the feminine from the order of things, and when taken literally, could even harm humankind in terms of the propagation of the species.

In the third phase of her works, she eventually resorted to the idea of the female lover. Apparently, in the French language, the word l'amant stands for a male lover, which depicts the male as an active subject. On the other hand, the female is called l'aimee or the beloved, an object of love. In other words, there is no French word that refers to a female lover. Irigaray comes up with an idea that is non-existent in her mother tongue, that of the $l^{\prime}$ amante $^{17}$ or the female lover. This emancipates the woman from being merely an object of love or lack of love thereof, but instead asserts her activity and subjectivity. It is the image of a female lover, the l'amante that resurrects the cadaver of the two lips metaphor, without this time isolating the female.

${ }^{14}$ Luce Irigaray, “When Our Lips Speak Together," trans. by Carolyn Burke, in Signs, 6:1 (Autumn, 1980): 71.

${ }^{15}$ Christine Holmund, "The Lesbian, the Mother, the Heterosexual Lover: Irigaray's Recodings of Difference," in Feminist Studies, 17:2 (Summer, 1991): 288.

${ }^{16}$ Ibid., 291.

${ }^{17}$ Ibid., 294. 
Earlier in this essay, we have talked a lot about the lotus feet. The lotus feet are symbolic of the reduction of the female into a maternal and reproducing body. The lotus feet stand up for a vision that the woman is merely a production machine. But while the being foot bound had socioeconomic roots in yesterday's China, present-day Shanghai, on the other hand, shows the symptoms of the socioeconomic system of capitalism in its women's quest for a western face. In a short documentary by journeyman.tv entitled "China's Tortured Beauties: Make Me Look Western," modern Chinese women, specifically those who live in or are near Shanghai, are depicted as being obsessed with the Western conception of beauty.

Having flat faces as opposed to the more three-dimensional-looking western visage, these Asian women would not only spend on exorbitantly priced cosmetics to alter their looks, but would even go so far as to undergo knife in surgeries that would give them, for instance, double eyelids and larger eyes. Since they are typically short, while the European models are tall, some Chinese women would even undergo leg-lengthening procedures. The legs would be sawn in half, a metal would be placed in between the broken bones, while the flesh and muscles would be extended. The healing process would be around twelve months; new bones are expected to form around the metal extender.

A link can be seen between the dominating attitude of capitalism, and the culture that totalizes the female. As the female is bombarded by images of what is supposedly beautiful through various forms of advertisements in media and social media, she develops anxiety and insecurities that are curable by purchasing commodities and availing of beauty services. Ironically, this cycle in turn turns the woman into a commodity herself. As Zimmerman, in her article "Revisiting Irigaray's Essay 'Women on the Market'" puts it, "Woman is not born a commodity, but rather becomes one. This is Luce Irigaray's argument." 18

For Zimmerman, there is a scholarship gap on Irigaray's engagement with Marxism. Moreover, there appears to be a desertion of Irigaray's Marxist feminism because of Marxism's veering away from essences. (Irigaray also pointed in the article mentioned above that Marxism's language of exchange pivots on male). Zimmerman argued that, "Revisiting Irigaray's and Marx's critiques of commodity in capitalism gives feminists the tools to understand the mechanism by which capitalism and patriarchy intersect to produce simultaneously in the twenty-first century late capitalism and postfeminism that conceal the continuous subordination of women." 19

18 Tegan Zimmerman, “Revisiting Irigaray's Essay 'Women on the Market,'” in Women's Studies: An Inter-Disciplinary Journal, 45:5 (2016): 425.

${ }^{19} \mathrm{Ibid}$.

(C) 2017 Elaine M. Lazaro

http://www.kritike.org/journal/issue 20/lazaro june2017.pdf

ISSN 1908-7330

(c) $)$ BY-NC-ND 
In line with the criticism on Irigaray as an essentialist mentioned above, it must be noted that $\mathrm{Xu}$ argues that these criticisms result from a lack of understanding of Irigaray's method. ${ }^{20}$ Irigaray's essentialism, for Xu, cannot be denied as it is really obvious in her works, but he contends, citing Lacan (whom Irigaray disagreed with), that biological essentialism is but a mimicry to the very-sexed order that she criticizes. Irigaray's emphasis on the biology of the female, which seems to tie the feminine identity to her genitalia or sex, made her unpopular in movements that emancipate the female from her body. Accordingly, Irigaray's feminism is a sort of a victim mindset. Whether Irigaray's essentialism is merely mimicry or not, it cannot be denied, nonetheless, that women's oppression, no matter what her sexual preference is, is historically tied to her genitals, and that her genitals, her sexuality, and her capacity to bear a child make her different from a man.

But going back to the discussion between commodification and women's body, Irigaray's philosophy shows that Western thinking positioned man as the subject and the earth as the object. It is for this reason that man has always felt free to apply his techniques upon the earth, thinking that the earth is an inexhaustible resource for things. It is important to note, however, that Western thinking is not something inherent in the west in terms of geography. For Levinas, who influenced Irigaray, particularly in her concept of alterity, Western thinking is instead an attitude, and something that can be possessed by whoever, in whichever time or place.

The danger with this kind of thinking, however, lies with the fact that this kind of attitude towards nature is easily applicable towards an other person. When the other is treated like an object for one's utilization, or when she is being applied with techniques, then she is being treated like an earth for one's utilization. Stephen Pluhacek characterizes man as essentially an economic being, i.e., as a gathering, a conglomeration of flesh and blood and historical existence. As an economic being, man is also predisposed to gather and to possess. ${ }^{21}$ And yet, being "economizing beings," there is also a danger to apply such economizing to an other that is not a "thing" to be possessed and hoarded. "This gathering takes various forms-war, patriarchy, matriarchy, consciousness, egology, representational structures-which must be brought into question." 22 It is from this questioning that "a new way of living and thinking can perhaps be discerned." 23

${ }^{20}$ Ping Xu, "Irigaray's Mimicry and the Problem of Essentialism," in Hypatia, 10:4 (Autumn, 1995): 76-89.

${ }^{21}$ Stephen Pluhacek, "To the Other as Other - Hearing, Listening, Understanding," in Paragraph: A Journal of Modern Critical Theory, 25:3 (2002): 47.

${ }^{22}$ Ibid.

${ }^{23} \mathrm{Ibid} ., 48$. 
Moreover, as was already said earlier, Irigaray likens the woman to the earth. Both the woman and the earth are exploited by man as his-tory would show. Apparently, this danger in exploiting the woman as if she were an object, just like the earth and nature, is also possible within the confines of one's home. When a woman is nearer, she becomes more fragile. It is easier to apply this to one's dwelling when proximity is no longer seen as an alternative to the domination of seeing, as an experience of something other that cannot be related to the self. In one's dwelling, the nearness of the Other, instead of a manifestation of her otherness, could be used for domination. This proximity to the feminine other shows that she is vulnerable and that she is truly alter or completely different, but it is also this proximity that puts her into danger. It is of no wonder then that the Yemen child brides experience abuse within the confines of their home. For, while in some other parts of the world, women are slowly being able to assert their alterity, in other parts of the world, such as in Yemen, women are still being drastically treated as if they were objects for disposal.

A critique on the too much generosity and welcome of the other is the displacement of who or what is at home. For to welcome the other, there is a presupposition that one must have his place in under the world. While such criticism poses the danger of totalization, the danger of the rebirth of another genocide, it is valid if it does not intend to harm the stranger coming from a strange land and when we are talking about the primacy of the ethical encounter, the beginning of one's recognition of an other. The fear of being displaced in one's home or being at-home is not something harmful towards the other when such fear is only a fear for oneself, in a way that one can no longer welcome or one is no longer capable of welcoming since oneself is also at a loss and disposed. What I am here trying to articulate is that the child, the child bride particularly, has to first have a home, has to understand her being at-home being amoral. It is only by first having an at-home can one begin to welcome the other. It is by first by being emplaced.

It is not uncommon in Yemen to marry off girls as young as eight or ten to men who could pass as their fathers or grandfathers. These families are often very poor and would be grateful to have one mouth less to feed, and thus by disposing their young girl, it benefits them economically. Many of these child brides would end up working for the families of their husbands as if they were slaves. Some (because some do not even) arrive at the hospital a few days after marriage because their fragile, small, but rather flexible and writhing young bodies were not able to take the consummation of such socioeconomic marriage. Their bodies were bodies still growing and not mature ones designed to carry a child. It is a form of violence to expect a child to carry in the body of her home someone other than herself.

(C) 2017 Elaine M. Lazaro

http://www.kritike.org/journal/issue 20/lazaro june2017.pdf

ISSN 1908-7330

(c) $)$ BY-NC-ND 
While Irigaray said that it is in fact in "the first moments of drawing near to one another that the other moves us the most, touching us in a global, unknowable, uncontrollable manner," we often end up, however, in making the other "our own-through knowledge, sensibility, culture. Entering our horizon, our world, the other loses the strangeness of his or her appeal." 24 Irigaray follows the thread of connecting the Western attitude to possess, which is guided by the logic of the same. The woman, usually associated with nature, nurture, and the earth, is easily seen as another victim of the capitalistic tendency to explore resources that eventually lead to exploitation.

It is of no wonder then that women are traded in the market just like the child brides. Women are priced and bargained and sold as merchandises not just in prostitution dens, cabarets, or cheap and sketchy bars. Women are traded and sold by the media, for example. They are being sold to the other women who are in turn sold to the capitalists, who would profit whenever they succeed in appealing to her insecurities, her flaws, and her very materiality (and as such we cannot here deny that her identity is essentially linked to her body). Fermon echoes Irigaray when she says that traditionally, women have always been "commodities, objects but never subjects of exchange." 25 While men are seen as entities that could rightly govern themselves, women are seen as children-like, and like objects and children, they are subject to being governed. ${ }^{26}$

\section{Epilogue}

Let them have oneness, with its prerogatives, its domination, its solipsisms: like the sun ... Our vital energies are spent in this wearisome labor of doubling and miming. We have been destined to reproduce-that sameness in which, for centuries, we have been the other. - Luce Irigaray

At the heart, however, of a culture that merely uses the woman as an object of exchange, and a culture that functions merely on the logic of object exchange are symbols, ${ }^{27}$ such as language. For Irigaray does not merely attempt to create a space to cultivate a culture specifically caring of the female; instead, what she did is an anthropology of a culture that is partial to

\footnotetext{
${ }^{24}$ Ibid., 45.

${ }^{25}$ Nicole Fermon, "Woman on the Global Market: Irigaray and the Democratic State," in Diacritics, 28:1 (1998): 120.

${ }^{26}$ Ibid., 124.

${ }^{27}$ Anne Caldwell, "The Subversion of Identity: Luce Irigaray and the Critique of Phallogocentrism," in Hypatia, 17:4 (Fall, 2003): 16.
} 
the masculine. ${ }^{28}$ By masculine, Irigaray is not simply referring to individuals who are born with penises. Masculinity is a character that can be possessed by every human being, symbolized by the perfectly straight penis. This "one" sex is a metaphor for a kind of worldview that reduces what is completely alter into the same. One way of diagnosing such culture is by examining language and symbolic objects, both of which are symbols. A culture, of course, is only mediated and thrives in symbols. Irigaray is not being biased to the female sex.

Even in as early as her Speculum of the Other Woman, Irigaray has been giving hints that the male is also a victim of his very "projects and projections." The male gender is also oppressed by the order of things that revert to the violence of the same. For instance, the male is being perpetually challenged to be able to prove that literally and figuratively, he is an erect and sturdy phallus that points upward directly. The sturdy and rather narrow definition of masculinity would confuse a lot of men and would force a great number to theatrically play that part of being macho lest they risk being mistaken for someone with a different gender preference.

Irigaray's project seems to be an attempt to find cracks into the sturdiness of the same by first characterizing the opposite of sameness or the masculine. However, Irigaray is not merely positing a binary or a second voice to break the monotony of the dialogue of the same. Instead of being another symbolic object to symbolize the new order of things, the female sex in the image of fissures does not simply become an other to the same, for its very otherness lie in the fact that it does not only mirror the sameness of the same. It comes from elsewhere and surprisingly possesses an otherness that is not only irreducible, but also too many in such a way that it does not simply succumb to the totalizing gaze of the same.

The oneness of the penis is an attitude. It is the same attitude possessed by those who totalized the victims of the Holocaust. It is the same attitude possessed by those who keep on interpreting the world in his own terms, based on his own comfort and preference and ambitions. The oneness of the penis that resists otherness is the attitude of playing deaf, of being tired of listening, of pretending to listen.

A culture that thrives in the symbolic dominion of the penis is partial to men and is very violent to women, but it does not mean that the males are exempted from its oppressive dominion. Even men who do not act like alpha males (who rather act theatrically sometimes) can be victims, especially when they are dubbed as gay or homosexuals even though their sexual preference is not really such. Males are also expected to play their part in prolonging the illusion of the oneness of the penis. In a sense, although the male culture is of

(C) 2017 Elaine M. Lazaro

http://www.kritike.org/journal/issue 20/lazaro june2017.pdf

ISSN 1908-7330

(cc) BY-NC-ND 
course essentially partial to men and is basically oppressive to women, which is the reason why Irigaray argues for a female culture, the male culture does not exempt all men from its oppression.

Because language is a symbol, just like gestures and symbolic objects, and because it is a foundation of a culture, it reflects in the everyday reality. By exemplifying how language is partial to men, she is actually showing that the everyday life is saturated by that partiality. Irigaray says:

If we continue to speak the same language to each other, we will produce the same story. Begin the same stories all over again. Don't you feel it? Listen: men and women around us all sound the same. Same arguments, same quarrels, same scenes. Same attractions and separations. Same difficulties, the impossibility of reaching each other. Same ... same .... Always the same. If we continue to speak this sameness, we speak to each other as men have spoken for centuries, as they taught us to speak, we will fail each other. ${ }^{29}$

Irigaray declares that the female should free themselves from the language spoken by the male, which is the same language used to speak about them, to price them and to measure them. ${ }^{30}$ It is only by means of breaking into this monologue that there is a possibility of new thought, a new frame of mind, new social structures, and new spaces for interaction. If the language partial to the male would continually dominate the world, then there will be no new thought. It can even be said that there really is no thinking amidst this consensus.

For that reason, her way of writing can be comparable to that of Friedrich Nietzsche, who was also very influential to her works. Nietzsche's way of writing is often characterized as aphoristic, if not poetic. She wrote in the same manner, doing an abuse of poetic license here and there in an attempt to speak a different language, being true to her own desire of carving a space of discourse for women. Thus, she says:

Speak just the same. Because your language doesn't follow just one thread, one course, or one pattern, we are in luck. You speak from everywhere at the same time. You touch me whole at the same time. In all senses. Why only one song, one discourse, one text at a time? To

\footnotetext{
${ }^{29}$ Irigaray, “When Our Lips Speak Together,” 69.

${ }^{30} \mathrm{Ibid}$.
} 
seduce, satisfy, fill one of my 'holes'? I don't have any, with you. We are not voids, lack which wait for sustenance .... ${ }^{31}$

Furthermore,

Let's quickly invent our own phrases, so that everywhere and always, we embrace. ${ }^{32}$

Department of Philosophy, University of Santo Tomas, Philippines

\section{References}

Caldwell, Anne, "The Subversion of Identity: Luce Irigaray and the Critique of Phallogocentrism," in Hypatia, 17:4 (Fall, 2003).

Crossley, Lucy, "PICTURED: The last living Chinese women with bound feet more than 100 years after the centuries-old symbol of beauty and status was banned," in Mail Online (8 June 2014), $<$ http://www.dailymail.co.uk/news/article-2652228/PICTURED-Theliving-Chinese-women-bound-feet-100-years-centuries-old-symbolbeauty-status-banned.html.>.

Fermon, Nicole, "Woman on the Global Market: Irigaray and the Democratic State," in Diacritics, 28:1 (1998).

Hirsh, Elizabeth and Olson, Gary. "Je-Luce Irigaray," trans. by Elizabeth Hirsh and Gaetan Brulotte, in JAC: A Journal of Rhetoric, Culture, and Politics, 16:3 (1995).

Holmund, Christine, "The Lesbian, the Mother, the Heterosexual Lover: Irigaray's Recodings of Difference," in Feminist Studies, 17:2 (Summer, 1991).

Irigaray, Luce, "Being Two, How Many Eyes Have We?" in Paragraph: A Journal of Modern Critical Theory, 25:3 (2002). Speculum of the Other Woman, trans. by Gillian C. Gill, (Ithaca New York: Cornell University Press, 1985). "When Our Lips Speak Together," trans. by Carolyn Burke, in Signs, 6:1 (Autumn, 1980).

Pluhacek, Stephen, "To the Other as Other - Hearing, Listening, Understanding," in Paragraph: A Journal of Modern Critical Theory, 25:3 (2002).

\footnotetext{
${ }^{31}$ Ibid., 73.
}

${ }^{32}$ Ibid., 77. 
Trani, Florinda, "From the Same to the Other," in Paragraph: A Journal of Modern Critical Theory, 25:3 (2002).

Vento, Marie, "One Thousand Years of Chinese Footbinding: Its Origins, Popularity and Demise," in Fordham University: Internet History Sourcebooks Project (7 March 1998), ed. by Paul Halsall, $<$ http://sourcebooks.fordham.edu/halsall/women/vento.asp $>$.

$\mathrm{Xu}$, Ping, "Irigaray's Mimicry and the Problem of Essentialism," in Hypatia, 10:4 (Autumn, 1995).

Zimmerman, Tegan, "Revisiting Irigaray's Essay 'Women on the Market,'” in Women's Studies: An Inter-Disciplinary Journal, 45:5 (2016). 